\title{
Review
}

Neurodegenerative Dis 2012;9:53-59

DOI: $10.1159 / 000333097$
Received: August 2, 2011

Accepted: September 13, 2011

Published online: November 26, 2011

\section{Using DNA Methylation to Understand Biological Consequences of Genetic Variability}

\author{
Dena G. Hernandez Andrew B. Singleton \\ Laboratory of Neurogenetics, National Institute on Aging, National Institutes of Health, Bethesda, Md., USA
}

\section{Key Words}

Methylation • Genetic variability · Quantitative trait loci •

Genome-wide association

\begin{abstract}
The advent of high-content genomic mapping technologies has provided numerous clues about the genetic architecture of complex disease and the tools with which to understand the biological framework resulting from this architecture. We believe that understanding and mapping epigenetic marks, in particular DNA methylation, which is suited to such assays, offers a timely opportunity in this context. Here, we make an argument for this work, describing this opportunity, the likely path ahead, and the problems and pitfalls associated with such work.

Copyright $\odot 2011$ S. Karger AG, Basel
\end{abstract}

\section{Introduction}

Single-nucleotide polymorphism genotyping technologies have afforded the opportunity to examine common genetic variation in a genome-wide, high-throughput manner. Hundreds of loci associated with complex disease and traits have been identified through genomewide association (GWA) studies [1]. The study of mende- lian disease, where pathogenic mutations in underlying genes result in changes in protein sequence or gene copy number, gave rise to the idea that risk loci identified by GWA would likely be confined to regions of the genome capable of altering the protein code. However, this idea became obsolete as many GWA loci mapped to noncoding regions of the genome. Although GWA studies have successfully identified loci capable of altering the risk for common complex disease by factors from 1.1- to 5.0-fold $[1,2]$, the biological basis for disease associations identified through GWA remains mostly unsolved. An approach widely used by us and others to better understand this phenomenon, centers on correlating risk variants with expression of proximal genes, effectively determining which risk loci are also expression quantitative trait loci (eQTL). There are several limitations to this method. Although eQTL analyses have offered a practical and useful path into disease etiology, this method offers resolution of only part of the picture. Many limitations of eQTL analyses have been discussed by us and others, and include the technical limitations of assays, availability of tissue of interest, inherent heterogeneity of tissue, and the cross-sectional nature of tissue acquisition. In the context of neurological disease, where human brain tissue is often used, these limitations may be particularly detrimental. The dynamic range and somewhat targeted nature of many expression methods are beginning to be addressed

\section{KARGER}

() 2011 S. Karger AG, Basel

Fax +4161306 1234

E-Mail karger@karger.ch

www.karger.com
Accessible online at:

www.karger.com/ndd
Dena G. Hernandez

Laboratory of Neurogenetics

National Institute on Aging

National Institutes of Health

Bethesda, MD 20892 (USA) 
by the application of RNA sequencing, rather than an array-based assay. Further, the confounding of assaying heterogeneous tissues and alterations in cellular composition associated with age and disease are also beginning to be addressed with methods that aim to isolate and assay single cell types. One limitation of expression assays in postmortem tissue that is difficult to solve is the crosssectional nature of sample collection. One can imagine that many expression and splicing effects important in disease, and perhaps mediated by disease-linked risk variants, may not be constitutive, but rather induced. In this respect, we believe that examining the epigenetic modification of DNA methylation offers valuable additional insight, because DNA methylation reveals local transcriptional potential rather than the current transcriptional profile, and as such may reveal the extent to which expression can plausibly change in response to an acute stimulus.

In this article, we discuss the investigation of DNA methylation as a quantitative trait influenced by genetics, particularly in the context of complex disease. This review is not meant to serve as a comprehensive review of epigenetics or quantitative trait mapping, nor is it meant to exclude other biological mediators of genetic risk loci, but rather to highlight what we see as an interesting opportunity to gain insight into complex biology.

\section{Understanding Pathobiology in Complex Disease}

Using traditional gene cloning to find genetic mutations provides a penetrant, often coding mutation with which to model disease. The path of biological investigation in these cases, while difficult, is clear. Creation of model systems that recapitulate some aspect of the aberrant gene has traditionally been used as a tool to study the disease mechanism. In contrast to highly penetrant alleles associated with monogenic disease, the risk loci implicated by GWA are associated with small effect sizes and, in the majority of cases, are not linked to nonsynonymous protein coding variants. A substantial gap still exists between single-nucleotide polymorphism associations from GWA studies and understanding how loci contribute to disease; however, clues are emerging through the study of gene expression. Given that many GWA loci do not map to coding changes or protein open reading frames, it is likely that a great deal of biologically and clinically important genetic variation exerts a pathobiological effect through differential gene expression and/or splicing, rather than point mutations in protein sequence. In this manner, genetic variability can have a direct impact on gene expression either quantitatively or qualitatively. Gene eQTL mapping has been used in an attempt to catalog, map and understand these effects. However, an additional, intermediate and plausible effect of genetic variability is on transcriptional potential through varying levels of local DNA methylation.

\section{Epigenetics and Its Importance in Complex Disease}

Epigenetics is the study of heritable changes in gene function caused by mechanisms other than changes in the underlying DNA sequence. Epigenetic modifications, such as DNA methylation, are heritable but potentially reversible, may alter throughout life and can be affected by the environment, such as lifestyle, diet and toxin exposure [3]. The study of epigenetics is an expanding field of research where technical breakthroughs have recently allowed the success of large-scale epigenomic studies. For example the discovery of CpG island shores was made [4], the human methylome was characterized at single nucleotide resolution [5], the putative identification of nonCpG methylation was made [6], and the roles of novel histone variants and modification have been defined [7-9].

Until recently, the majority of epigenetic research focused on the study of cancer. Not only has global DNA hypomethylation consistently been observed in many cancers but all three types of normal epigenetic modifications of DNA, including chromatin modifications, DNA methylation and genomic imprinting, are altered in cancer cells $[10,11]$. As the field of epigenetics research has expanded over the last few years, epigenetic alterations have been found to be linked to disorders such as metabolic disorders [12] cardiovascular diseases [13-15] and myopathies [16].

There is also strong evidence suggesting a relationship between epigenetic alterations and neurological disorders. For example, hypermethylation of the FMR1 promoter has been described in fragile X syndrome patients [17], along with hypermethylation of gene promoters FXN in Friedreich's ataxia, SMN2 in spinal muscular atrophy, and neprilysin (also known as membrane metalloendopeptidase) in Alzheimer's disease [18]. Conversely, the overexpression of tumor necrosis factor $\alpha$ in the substantia nigra of Parkinson's disease patients is associated with promoter hypomethylation, inducing apoptosis in neuronal cells [19]. Neurodegenerative disorders such as Alzheimer's and Parkinson's disease are believed to have 
a multifactorial origin arising from a combination of risk factors and susceptibility genes, where age, diet, lifestyle and level of education are all correlated with the onset and severity of the sporadic forms [20, 21]. The mode(s) in which environmental factors and susceptibility genes interact to cause disease are not fully understood; however, epigenetic mechanisms may provide a link between genes and environment.

There are three major categories of epigenetic modifications: DNA methylation, histone modification and nucleosome positioning [22]. When studying epigenetics, it is important to understand that the observed outcome of epigenetic modifications is the sum of their interactions and feedback mechanisms. However, the study of DNA methylation as a single modification has the ability to convey important epigenetic information by distinguishing regions of transcriptional silence or transcriptional potential. Because subsets of potential target $\mathrm{CpG}$ sites are methylated within the genome, the signature of methylated sites can easily be distinguished. This fact makes the study of CpG methylation attractive, especially on a genome-wide level.

\section{CpG Methylation}

DNA methylation is believed to be an important epigenetic regulator of chromatin structure and function making it a key regulator of gene expression, splicing, growth and differentiation in virtually all tissues, including brain [22]. DNA methylation is perhaps the most widely studied epigenetic modification and is the oldest epigenetic mechanism known to correlate with gene expression [23]. In its most fundamental form, DNA methylation consists of the addition of a methyl group at the cytosine residue of $\mathrm{CpG}$ dinucleotides. Such additions to DNA are associated with the repression and silencing of gene expression and are central to genomic imprinting and $\mathrm{X}$ chromosome inactivation. In general, the $\mathrm{CpG}$ sites within the landscape of genomic DNA in mammals tend to be methylated [24]. The distribution of DNA methylation throughout the genome shows enrichment at noncoding regions and interspersed repetitive elements, but not in CpG islands of active genes [25]. CpG islands are clusters of $\mathrm{CpG}$ dinucleotides that have a strong association with gene promoters and housekeeping genes [26]. CpG islands are largely unmethylated throughout the genome in normal cells, allowing access to the transcriptional machinery, facilitating transcription. Thus, while an unmethylated $\mathrm{CpG}$ island in a gene promoter does not necessarily mean active expression of the associated gene, it does suggest there is transcription potential. There are approximately $30,000 \mathrm{CpG}$ islands in the human genome, and recent studies have identified a growing number of methylated islands in nonpathological somatic tissues [27].

Traditionally, a CpG island is defined as having a G + $\mathrm{C}$ content greater than $50 \%$, an observed versus expected ratio for the occurrence of $\mathrm{CpGs}$ of more than 0.6 and a minimum size of $200 \mathrm{bp}$. However, the definition of $\mathrm{CpG}$ island continues to evolve. A recent study revised the traditional rules of $\mathrm{CpG}$ island prediction in order to exclude other GC-rich genomic sequences such as Alu repeats. In comparison to previous definitions, it was shown that DNA regions immediately $5^{\prime}$ to genes with a $\mathrm{G}+\mathrm{C}$ content $>55 \%$ and an observed versus expected ratio of $\mathrm{CpG}$ dinucleotides of $>0.65$, both in a track of 500 bp or longer, are more likely to be true CpG islands [28]. Seventy-five percent of transcription start sites and $88 \%$ of active promoters are associated with CpG-rich sequences [29]. Although research has typically focused on CpG islands spanning the $5^{\prime}$ end of the regulatory region of genes, it is now evident that variation in methylation occurs more often in the 'shores' of CpG islands versus within the islands themselves. It appears that around $76 \%$ of methylated sites occur a short distance away from $\mathrm{CpG}$ islands, with only $6 \%$ found within the islands themselves. Interestingly, most tissue-specific DNA methylation occurs in these $\mathrm{CpG}$ island shores, up to 2,000 base pairs away from $\mathrm{CpG}$ islands [4]. Additionally, a recent study revealed an important role for intergenic DNA methylation in the regulation of alternative promoters within gene bodies [30]. Intergenic methylation appears to modulate gene expression and splice variants, and $\mathrm{CpG}$ islands in introns can serve as promoters for noncoding RNA regulatory functions [31]. As research focuses on the most widely studied epigenetic modification, the complexity and significance of DNA methylation will continue to be highlighted.

\section{DNA Methylation as a Quantitative Trait}

The expression profile of a cell and its response to environmental signals effectively define its overall phenotype. Using gene expression as a quantitative trait has successfully identified genetic modifiers of gene expression. However, assaying DNA methylation as an intermediary between genetic variation and gene expression patterns provides a new and, unlike gene expression, stable mea- 
sure of the cellular phenotype. Quantitative measures of DNA methylation provide a chromatin signature of cellular transcriptional potential that is preserved and can be regenerated during cell division. DNA methylation has been shown to influence gene expression in an age-dependent and tissue-dependent manner [32, 33], characteristics that are potentially important for the study of neurodegenerative disease, where distinct regions of brain tissue and/orcell types are compromised in an age-dependent manner. Therefore, the study of QTL influencing epigenetic regulators of gene expression such as the covalent modifications of DNA are highly attractive as a means to further explore the molecular pathology of neurodegenerative disease beyond RNA quantification.

With a focus on the study of the genetics of age-related neurodegenerative disease [34-37], one of our critical goals is to determine the immediate biological consequences of disease-associated common genetic variation in the human brain. As discussed above, two functional, quantitative variables that can efficiently be investigated from a genome-wide perspective are mRNA expression and DNA methylation. Combining these data with QTL analysis allows a systematic, genome-wide, and relatively hypothesis-free investigation into the effect of common genetic variability on important functional variables.

\section{DNA Methylation and Aging}

Neurodegenerative diseases are frequently late onset, implying there is a biological characteristic that changes as a person ages. One unvarying factor for each disease is that neurons steadily lose function as the disease progresses with age. The biochemistry of aging is complex with significant alterations occurring in proteins, lipids and nucleic acids. Differential DNA methylation has been shown to be age related $[38,39]$, and methylation of DNA sequences within or near regulatory elements has been shown to suppress gene expression through effects on DNA binding proteins and chromatin structure [40]. Indeed, both increases and decreases in DNA methylation have been shown to occur with aging contingent upon the tissue and the gene [40]. It is possible that disregulation of DNA methylation with age promotes or exacerbates pathobiological consequences. Therefore, it is an important undertaking to understand the effects of DNA methylation on the normal aging brain. This new understanding will provide a foundation for gaining biological insight into age-related neurodegenerative diseases such as Parkinson's and Alzheimer's diseases.

\section{DNA Methylation Analysis Tools}

The methylation signature in a genomic DNA sample is complex as it represents the CpG methylation levels from a compilation of cells within the DNA sample. These cells are likely to have varying levels of DNA methylation that contribute to the overall signal. Assessing CpG methylation can be done for the pattern of methylated $\mathrm{CpG}$ sites along a sequence for individual DNA molecules or as an average methylation signal at a single genomic locus across many DNA molecules. Techniques to comprehensively characterize DNA methylation patterns are the most highly developed of the epigenetic methods.

Standard molecular biology techniques such as PCR and cloning erase DNA methylation marks; therefore, DNA must be pretreated to reveal the presence or absence of the methyl group at cytosine residues. There are three different initial treatments that can be used: endonuclease digestion, affinity enrichment and bisulfite conversion.

Techniques designed to pretreat DNA for methylation analysis were initially confined to localized regions of the genome; however, many methods now enable DNA methylation analysis on a genome-wide scale, including the bisulfite treatment of DNA. Bisulfite conversion is the most conventional approach for pretreatment and is considered the gold standard for determining DNA methylation status because it offers single CpG resolution [41].

Bisulfite treatment converts unmethylated cytosines to uracil while leaving methylated cytosines unconverted [42-44]. DNA can then be amplified or hybridized to arrays $[45,46]$. One microgram of bisulfite-converted DNA can now be used to ascertain quantitative measurements of DNA methylation for up to $450,000 \mathrm{CpG}$ dinucleotides on genome-wide methylation microarrays, such as the Illumina Infinium Human Methylation 450 array. The Infinium Methylation Assay uses two different bead types to detect CpG methylation. One bead type matches the unmethylated $\mathrm{CpG}$ site, and the other type matches the methylated site. The level of methylation for the interrogated locus is determined by calculating the ratio of the fluorescent signals from the methylated versus unmethylated sites. The field of epigenomics has flourished with the use of microarray hybridization techniques adopted from gene expression and genome-based assays to profile histone modifications and whole-genome DNA methylation patterns [47-50].

Bisulfite treatment of DNA in conjunction with nextgeneration sequencing can be used to decode the methylation status of the entire genome [6]. However, due to 
the high costs currently associated with large-scale sequencing, other methods concentrating on more limited sequencing of genomic regions have been developed, such as reduced representation bisulfite sequencing [51], which is a random approach for large-scale high-resolution DNA methylation analysis, where only a subset of the genome is analyzed. DNA is digested with methylationinsensitive restriction enzyme $(M s p \mathrm{I})$ to remove much of the unmethylated regions of the genome, then only DNA fragments of a specified length are bisulfite sequenced, consisting mostly of methylated DNA.

Although bisulfite treatment of DNA has long been considered a superior technique for measuring DNA methylation status, it does have disadvantages. Bisulfite conversion typically calls for larger quantities of sample DNA which can degrade following chemical treatment, it can be limited by incomplete conversion of all unmethylated cytosines to uracils, and bisulfite conversion cannot discriminate between methylcytosine and hydroxymethylcytosine. Alternative assessments of methylation status are based on enrichment of methylated DNA with immunoprecipitation (MeDIP-seq) or affinity purification (MethylCap-seq) and subsequent analysis of enriched sequences using microarrays or sequencing [52]. The HELP assay (HpaII fragment enrichment by ligationmediated PCR) pretreats DNA with methylation-sensitive and insensitive restriction endonuclease digestion. Subsequent comparative analysis of the resulting fragments using microarray or sequencing is used for the determination of the methylation state of restriction sites [53]. Several methods have been developed to map DNA methylation on a genome-wide scale. These methods, while diverse in technique, have been shown to produce concordant results [54].

\section{Practical Application of DNA Methylation QTL Mapping}

One of the particularly compelling factors of generating large-scale data to map and understand genetic variability and DNA methylation is that these data can be rapidly and repeatedly mined and augmented by the community. We have performed initial experiments in this regard, combining both genome-wide genotyping and array-based assays of DNA methylation that examine methylation levels at approximately $27,000 \mathrm{CpG}$ sites in 4 distinct regions of neurologically normal brains $[55,56]$. Similarly to previous work in the eQTL field, this showed an abundance of QTLs for DNA methylation, and an ex- treme enrichment of signals when the genetic variability linked to methylation status was close to the $\mathrm{CpG}$ site in question. This effort and the public posting of these data have allowed us and others to examine the effects of disease-linked variants on both gene expression and DNA methylation in the human brain $[34,57-59]$. One would expect that an expansion of this work, to include more brain regions, and a larger series of samples will bring a greater level of resolution in the mapping of genetic loci that control local DNA methylation levels. Further, the use of methods to isolate cell types, such as neuronal enrichment by NeuN-based cell sorting offers the ability to assay DNA from more homogenous populations of cells extracted from human brain [60].

\section{Conclusions}

Understanding the genetic control of biological processes is an important goal in the postgenome era. DNA methylation signatures are key in determining cellular differentiation and tissue-specific expression patterns. Moreover, assaying DNA methylation provides a window into the transcriptional potential of a cell type or tissue, rather than the cross-sectional view of transcription generally offered by expression analysis. We believe that comprehensive analysis of $\mathrm{CpG}$ methylation levels and chronological age has the potential to provide insight into coordinated changes in DNA methylation during aging, perhaps providing a starting point for understanding the underlying mechanisms of aging and age-related diseases.

Much of the technology required to comprehensively and accurately assay and link genetic variation and DNA methylation is now in place, and we believe that significant progress in understanding the relationship between genetics and epigenetics can be made in the near future. Further, we believe that the future refinement of these methods to allow their use on single cell types and perhaps even in situ within tissue will offer even clearer insight into this relationship.

\section{Acknowledgements}

This work was supported by the Intramural Research Program of the National Institute on Aging, National Institutes of Health, Department of Health and Human Services (project No. Z01 AG000932-03). 


\section{References}

$>1$ Hindorff LA, Sethupathy P, Junkins HA, Ramos EM, Mehta JP, Collins FS, Manolio TA: Potential etiologic and functional implications of genome-wide association loci for human diseases and traits. Proc Natl Acad Sci USA 2009; 106:9362-9367.

$>2$ Hardy J, Trabzuni D, Ryten M: Whole genome expression as a quantitative trait. Biochem Soc Trans 2009;37:1276-1277.

$>3$ Mill J: Toward an integrated genetic and epigenetic approach to Alzheimer's disease. Neurobiol Aging 2011;32:1188-1191.

$>4$ Doi A, Park IH, Wen B, Murakami P, Aryee MJ, Irizarry R, Herb B, Ladd-Acosta C, Rho J, Loewer S, Miller J, Schlaeger T, Daley GQ, Feinberg AP: Differential methylation of tissue- and cancer-specific CpG island shores distinguishes human induced pluripotent stem cells, embryonic stem cells and fibroblasts. Nat Genet 2009;41:1350-1353.

$>5$ Irizarry RA, Ladd-Acosta C, Wen B, Wu Z, Montano C, Onyango P, Cui H, Gabo K, Rongione M, Webster M, Ji H, Potash JB, Sabunciyan S, Feinberg AP: The human colon cancer methylome shows similar hypoand hypermethylation at conserved tissuespecific CpG island shores. Nat Genet 2009; 41:178-186.

6 Lister R, Pelizzola M, Dowen RH, Hawkins RD, Hon G, Tonti-Filippini J, Nery JR, Lee L, Ye Z, Ngo QM, Edsall L, Antosiewicz-Bourget J, Stewart R, Ruotti V, Millar AH, Thomson JA, Ren B, Ecker JR: Human DNA methylomes at base resolution show widespread epigenomic differences. Nature 2009;462: 315-322.

7 Dawson MA, Bannister AJ, Gottgens B, Foster SD, Bartke T, Green AR, Kouzarides T: JAK2 phosphorylates histone H3Y41 and excludes HPlalpha from chromatin. Nature 2009;461:819-822.

$>8$ Hurd PJ, Bannister AJ, Halls K, Dawson MA, Vermeulen M, Olsen JV, Ismail H, Somers J, Mann M, Owen-Hughes T, Gout I, Kouzarides T: Phosphorylation of histone $\mathrm{H} 3 \mathrm{Thr}$ 45 is linked to apoptosis. J Biol Chem 2009; 284:16575-16583.

>9 Zhao Q, Rank G, Tan YT, Li H, Moritz RL, Simpson RJ, Cerruti L, Curtis DJ, Patel DJ, Allis CD, Cunningham JM, Jane SM: PRMT5-mediated methylation of histone H4R3 recruits DNMT3A, coupling histone and DNA methylation in gene silencing. Nat Struct Mol Biol 2009;16:304-311.

10 Fazzari MJ, Greally JM: Introduction to epigenomics and epigenome-wide analysis. Methods Mol Biol 2010;620:243-265.

-11 Fazzari MJ, Greally JM: Epigenomics: beyond CpG islands. Nat Rev Genet 2004;5: 446-455.

-12 Symonds ME, Sebert SP, Hyatt MA, Budge $\mathrm{H}$ : Nutritional programming of the metabolic syndrome. Nat Rev Endocrinol 2009;5: 604-610.
13 Turunen MP, Aavik E, Yla-Herttuala S: Epigenetics and atherosclerosis. Biochim Biophys Acta 2009;1790:886-891.

14 Hang CT, Yang J, Han P, Cheng HL, Shang C, Ashley E, Zhou B, Chang CP: Chromatin regulation by Brg1 underlies heart muscle development and disease. Nature 2010;466: 62-67.

15 Movassagh M, Choy MK, Goddard M, Bennett MR, Down TA, Foo RS: Differential DNA methylation correlates with differential expression of angiogenic factors in human heart failure. PLoS One 2010;5:e8564.

16 Zeng W, de Greef JC, Chen YY, Chien R, Kong X, Gregson HC, Winokur ST, Pyle A, Robertson KD, Schmiesing JA, Kimonis VE, Balog J, Frants RR, Ball AR Jr, Lock LF, Donovan PJ, van der Maarel SM, Yokomori K: Specific loss of histone H3 lysine 9 trimethylation and HP1gamma/cohesin binding at D4Z4 repeats is associated with facioscapulohumeral dystrophy (FSHD). PLoS Genet 2009;5:e1000559.

17 Gheldof N, Tabuchi TM, Dekker J: The active FMR1 promoter is associated with a large domain of altered chromatin conformation with embedded local histone modifications. Proc Natl Acad Sci USA 2006;103:1246312468.

18 Urdinguio RG, Sanchez-Mut JV, Esteller M: Epigenetic mechanisms in neurological diseases: genes, syndromes, and therapies. Lancet Neurol 2009;8:1056-1072.

19 Pieper HC, Evert BO, Kaut O, Riederer PF, Waha A, Wullner U: Different methylation of the TNF-alpha promoter in cortex and substantia nigra: implications for selective neuronal vulnerability. Neurobiol Dis 2008; 32:521-527.

20 Gao HM, Hong JS: Gene-environment interactions: key to unraveling the mystery of Parkinson's disease. Prog Neurobiol 2011;94: $1-19$.

21 Chouliaras L, Rutten BP, Kenis G, Peerbooms O, Visser PJ, Verhey F, van Os J, Steinbusch HW, van den Hove DL: Epigenetic regulation in the pathophysiology of Alzheimer's disease. Prog Neurobiol 2010;90: 498-510.

22 Portela A, Esteller M: Epigenetic modifications and human disease. Nat Biotechnol 2010;28:1057-1068.

23 Razin A, Riggs AD: DNA methylation and gene function. Science 1980;210:604-610.

24 Herman JG, Baylin SB: Gene silencing in cancer in association with promoter hypermethylation. N Engl J Med 2003;349:20422054.

25 Bird AP: CpG-rich islands and the function of DNA methylation. Nature 1986;321:209213.

26 Gardiner-Garden M, Frommer M: CpG islands in vertebrate genomes. J Mol Biol 1987; 196:261-282.
27 Shen L, Kondo Y, Guo Y, Zhang J, Zhang L, Ahmed S, Shu J, Chen X, Waterland RA, Issa JP: Genome-wide profiling of DNA methylation reveals a class of normally methylated CpG island promoters. PLoS Genet 2007;3: 2023-2036.

28 Takai D, Jones PA: Comprehensive analysis of CpG islands in human chromosomes 21 and 22. Proc Natl Acad Sci USA 2002;99: 3740-3745.

29 Zhou H, Hu H, Lai M: Non-coding RNAs and their epigenetic regulatory mechanisms. Biol Cell 2010;102:645-655.

30 Maunakea AK, Nagarajan RP, Bilenky M, Ballinger TJ, D’Souza C, Fouse SD, Johnson BE, Hong C, Nielsen C, Zhao Y, Turecki G, Delaney A, Varhol R, Thiessen N, Shchors K, Heine VM, Rowitch DH, Xing X, Fiore C, Schillebeeckx M, Jones SJ, Haussler D, Marra MA, Hirst M, Wang T, Costello JF: Conserved role of intragenic DNA methylation in regulating alternative promoters. Nature 2010;466:253-257.

31 Tost J: Epigenetics. Norfolk, Caister Academic Press, 2008.

32 De Pinho RA: The age of cancer. Nature 2000;408:248-254.

33 Issa JP: CpG-island methylation in aging and cancer. Curr Top Microbiol Immunol 2000; 249:101-118.

34 International Parkinson Disease Genomics Consortium, Nalls MA, Plagnol V, Hernandez DG, Sharma M, Sheerin UM, Saad M, Simon-Sanchez J, Schulte C, Lesage S, Sveinbjornsdottir S, Stefansson K, Martinez M, Hardy J, Heutink P, Brice A, Gasser T, Singleton $\mathrm{AB}$, Wood NW: Imputation of sequence variants for identification of genetic risks for Parkinson's disease: a meta-analysis of genome-wide association studies. Lancet 2011; 377:641-649.

35 Simon-Sanchez J, Schulte C, Bras JM, Sharma M, Gibbs JR, Berg D, Paisan-Ruiz C, Lichtner P, Scholz SW, Hernandez DG, Kruger R, Federoff M, Klein C, Goate A, Perlmutter J, Bonin M, Nalls MA, Illig T, Gieger C, Houlden H, Steffens M, Okun MS, Racette BA, Cookson MR, Foote KD, Fernandez HH, Traynor BJ, Schreiber S, Arepalli S, Zonozi R, Gwinn K, van der Brug M, Lopez G, Chanock SJ, Schatzkin A, Park Y, Hollenbeck A, Gao J, Huang X, Wood NW, Lorenz D, Deuschl G, Chen H, Riess O, Hardy JA, Singleton $\mathrm{AB}$, Gasser T: Genome-wide association study reveals genetic risk underlying Parkinson's disease. Nat Genet 2009;41:1308-1312.

36 Matarin M, Brown WM, Scholz S, SimonSanchez J, Fung HC, Hernandez D, Gibbs JR, De Vrieze FW, Crews C, Britton A, Langefeld CD, Brott TG, Brown RD Jr, Worrall BB, Frankel M, Silliman S, Case LD, Singleton A, Hardy JA, Rich SS, Meschia JF: A genomewide genotyping study in patients with ischaemic stroke: initial analysis and data release. Lancet Neurol 2007;6:414-420. 
-37 Schymick JC, Scholz SW, Fung HC, Britton A, Arepalli S, Gibbs JR, Lombardo F, Matarin $M$, Kasperaviciute D, Hernandez DG, Crews C, Bruijn L, Rothstein J, Mora G, Restagno G, Chio A, Singleton A, Hardy J, Traynor BJ: Genome-wide genotyping in amyotrophic lateral sclerosis and neurologically normal controls: first stage analysis and public release of data. Lancet Neurol 2007;6: 322-328.

38 Gopisetty G, Ramachandran K, Singal R: DNA methylation and apoptosis. Mol Immunol 2006;43:1729-1740.

- 39 Ottaviano YL, Issa JP, Parl FF, Smith HS, Baylin SB, Davidson NE: Methylation of the estrogen receptor gene $\mathrm{CpG}$ island marks loss of estrogen receptor expression in human breast cancer cells. Cancer Res 1994;54: 2552-2555.

40 Richardson B: Impact of aging on DNA methylation. Ageing Res Rev 2003;2:245261.

-41 Ehrich M, Turner J, Gibbs P, Lipton L, Giovanneti M, Cantor C, van den Boom D: Cytosine methylation profiling of cancer cell lines. Proc Natl Acad Sci USA 2008; 105: 4844-4849.

-42 Bibikova M, Lin Z, Zhou L, Chudin E, Garcia EW, Wu B, Doucet D, Thomas NJ, Wang Y, Vollmer E, Goldmann T, Seifart C, Jiang W, Barker DL, Chee MS, Floros J, Fan JB: Highthroughput DNA methylation profiling using universal bead arrays. Genome Res 2006; 16:383-393.

-43 Clark SJ, Harrison J, Paul CL, Frommer M: High sensitivity mapping of methylated cytosines. Nucleic Acids Res 1994;22:2990 2997.

-44 Clark SJ, Statham A, Stirzaker C, Molloy PL, Frommer M: DNA methylation: bisulphite modification and analysis. Nat Protoc 2006; 1:2353-2364.

45 Fraga MF, Esteller M: DNA methylation: a profile of methods and applications. Biotechniques 2002;33:632, 634, 636-649.

-46 Pomraning KR, Smith KM, Freitag M: Genome-wide high throughput analysis of DNA methylation in eukaryotes. Methods 2009;47:142-150.

-47 Hatada I, Kato A, Morita S, Obata Y, Nagaoka K, Sakurada A, Sato M, Horii A, Tsujimoto A, Matsubara K: A microarray-based method for detecting methylated loci. J Hum Genet 2002;47:448-451.
48 Van Steensel B, Delrow J, Henikoff S: Chromatin profiling using targeted DNA adenine methyltransferase. Nat Genet 2001;27:304308.

49 Huang TH, Perry MR, Laux DE: Methylation profiling of $\mathrm{CpG}$ islands in human breast cancer cells. Hum Mol Genet 1999;8:459470.

50 Beck S, Olek A, Walter J: From genomics to epigenomics: a loftier view of life. Nat Biotechnol 1999;17:1144.

$51 \mathrm{Gu} \mathrm{H}$, Smith ZD, Bock C, Boyle P, Gnirke A, Meissner A: Preparation of reduced representation bisulfite sequencing libraries for genome-scale DNA methylation profiling. Nat Protoc 2011;6:468-481.

52 Rauch TA, Pfeifer GP: The MIRA method for DNA methylation analysis. Methods $\mathrm{Mol}$ Biol 2009;507:65-75.

53 Suzuki M, Greally JM: DNA methylation profiling using HpaII tiny fragment enrichment by ligation-mediated PCR (HELP). Methods 2010;52:218-222.

54 Bock C, Tomazou EM, Brinkman AB, Muller F, Simmer F, Gu H, Jager N, Gnirke A, Stunnenberg HG, Meissner A: Quantitative comparison of genome-wide DNA methylation mapping technologies. Nat Biotechnol 2010;28:1106-1114.

55 Hernandez DG, Nalls MA, Gibbs JR, Arepalli S, van der Brug M, Chong S, Moore M, Longo DL, Cookson MR, Traynor BJ, Singleton AB: Distinct DNA methylation changes highly correlated with chronological age in the human brain. Hum Mol Genet 2011;20: 1164-1172.

56 Gibbs JR, van der Brug MP, Hernandez DG, Traynor BJ, Nalls MA, Lai SL, Arepalli S, Dillman A, Rafferty IP, Troncoso J, Johnson R, Zielke HR, Ferrucci L, Longo DL, Cookson MR, Singleton AB: Abundant quantitative trait loci exist for DNA methylation and gene expression in human brain. PLoS Genet 2010;6:e1000952.

57 International Parkinson's Disease Genomics Consortium and Wellcome Trust Case Control Consortium: A two-stage meta-analysis identifies several new loci for Parkinson's disease. PLoS Genet 2011; 7:e1002142.
58 Guerreiro RJ, Beck J, Gibbs JR, Santana I, Rossor MN, Schott JM, Nalls MA, Ribeiro H, Santiago B, Fox NC, Oliveira C, Collinge J, Mead S, Singleton A, Hardy J: Genetic variability in CLU and its association with Alzheimer's disease. PLoS One 2010;5:e9510.

59 Hoglinger GU, Melhem NM, Dickson DW, Sleiman PM, Wang LS, Klei L, Rademakers R, de Silva R, Litvan I, Riley DE, van Swieten JC, Heutink P, Wszolek ZK, Uitti RJ, Vandrovcova J, Hurtig HI, Gross RG, Maetzler W, Goldwurm S, Tolosa E, Borroni B, Pastor P, Group PSPGS, Albin RL, Alonso E, Antonini A, Apfelbacher M, Arnold SE, Avila J, Beach TG, Beecher S, Berg D, Bird TD, Bogdanovic N, Boon AJ, Bordelon Y, Brice A, Budka H, Canesi M, Chiu WZ, Cilia R, Colosimo C, De Deyn PP, de Yebenes JG, Kaat LD, Duara R, Durr A, Engelborghs S, Fabbrini G, Finch NA, Flook R, Frosch MP, Gaig C, Galasko DR, Gasser T, Gearing M, Geller ET, Ghetti B, Graff-Radford NR, Grossman M, Hall DA, Hazrati LN, Hollerhage M, Jankovic J, Juncos JL, Karydas A, Kretzschmar HA, Leber I, Lee VM, Lieberman AP, Lyons KE, Mariani C, Masliah E, Massey LA, McLean CA, Meucci N, Miller BL, Mollenhauer B, Moller JC, Morris HR, Morris C, O'Sullivan SS, Oertel WH, Ottaviani D, Padovani A, Pahwa R, Pezzoli G, Pickering-Brown S, Poewe W, Rabano A, Rajput A, Reich SG, Respondek G, Roeber S, Rohrer JD, Ross OA, Rossor MN, Sacilotto G, Seeley WW, Seppi K, Silveira-Moriyama L, Spina S, Srulijes K, St George-Hyslop P, Stamelou M, Standaert DG, Tesei S, Tourtellotte WW, Trenkwalder C, Troakes C, Trojanowski JQ, Troncoso JC, Van Deerlin VM, Vonsattel JP, Wenning GK, White CL, Winter P, Zarow C, Zecchinelli AL, Cantwell LB, Han MR, Dillman A, van der Brug MP, Gibbs JR, Cookson MR, Hernandez DG, Singleton AB, Farrer MJ, Yu CE, Golbe LI, Revesz T, Hardy J, Lees AJ, Devlin B, Hakonarson H, Muller U, Schellenberg GD: Identification of common variants influencing risk of the tauopathy progressive supranuclear palsy. Nat Genet 2011;43:699-705.

60 Matevossian A, Akbarian S: Neuronal nuclei isolation from human postmortem brain tissue. J Vis Exp 2008;20:914. 